\title{
Regime shifts between macrophytes and phytoplankton - concepts beyond shallow lakes, unravelling stabilizing mechanisms and practical consequences
}

\author{
Sabine Hilt* \\ Leibniz-Institute of Freshwater Ecology and Inland Fisheries, Müggelseedamm 301, 12587 Berlin, Germany. \\ * Corresponding author: hilt@igb-berlin.de
}

Received: 04/11/2014 Accepted: 11/06/2015

\begin{abstract}
Regime shifts between macrophytes and phytoplankton -concepts beyond shallow lakes, unravelling stabilizing mechanisms and practical consequences

Feedback mechanisms between macrophytes and water clarity resulting in the occurrence of alternative stable states have been described in a theoretical concept for shallow lakes. Here, I review recent studies applying the concept to other freshwater systems, unravelling stabilizing mechanisms and discussing consequences of regime shifts. Recent modelling studies predict that abrupt changes between clear and turbid water states can also occur in lowland rivers, both in time and in space. These findings were supported by long-term data from rivers in Spain and Germany. A deep lake model revealed that submerged macrophytes may also significantly reduce phytoplankton biomass by 50-15\% in 100-11 m deep and oligotrophic lakes. Some of the mechanisms stabilizing clear-water conditions are still far from fully understood. Available data suggest that the macrophyte community composition affects number and type of mechanisms stabilizing clear-water conditions. Allelopathic effects of macrophytes on phytoplankton are no longer doubted, however, bacterial colonization of macrophytes and phytoplankton, phytoplankton interactions, local adaptations and strain-specific sensitivities have been found to modulate these interactions. New aspects on stability properties of shallow lake ecosystems arose from experimental and modelling studies on terrestrial organic matter input, both in dissolved (tDOM) and particulate (tPOM) form. These suggest that the likelihood that shallow lakes will shift to or stay in the turbid state is enhanced with a predicted future increase in tDOM and tPOM input. Shallow lake restoration still suffers from knowledge gaps such as the role of propagule availability and dispersal for the re-establishment of a diverse submerged macrophyte vegetation. The importance of lake regime shifts, however, is increasingly supported by studies on quantitative consequences for processes such as primary production, carbon emissions and carbon burial.
\end{abstract}

Key words: Allelopathy, bistability, carbon balance, lake restoration, river.

\section{RESUMEN}

Cambios entre el régimen de macrófitos y el de fitoplancton: conceptos más allá de los lagos poco profundos, descifrando los mecanismos de estabilización y consecuencias prácticas

Existe el concepto teórico para lagos poco profundos de los mecanismos de retroalimentación que ocurren entre los macrófitos y la fase clara del agua y que resultan en estados alternativos de estabilidad. En este trabajo, reviso estudios recientes aplicando este concepto a otros sistemas de aguas continentales, descifrando los mecanismos de estabilización y discutiendo las consecuencias de los cambios de régimen. Modelos recientes predicen que pueden ocurrir cambios abruptos entre estados de aguas claras y turbias también en las partes bajas de los ríos, tanto en el tiempo como en el espacio. Estos resultados se apoyan en largas series temporales de datos en ríos de España y Alemania. Un modelo en un lago profundo reveló que los macrófitos sumergidos también pueden reducir significativamente la biomasa de fitoplancton entre un 50 y $15 \%$ en lagos oligotróficos de entre 11 y $100 \mathrm{~m}$ de profundidad. Pero los mecanismos que determinan las condiciones para la estabilidad de la fase de aguas claras están aún lejos de ser bien comprendidos. Los datos disponibles sugieren que la composición de la comunidad de macrófitos afecta el número y tipo de mecanismos que estabilizan las condiciones de aguas claras. No hay duda de los efectos alelopáticos generados por los macrófitos en el fitoplancton, sin embargo, se ha encontrado que la colonización bacteriana en macrófitos y fitoplancton, las interacciones del fitoplancton, las adaptaciones locales y la sensibilidad específica 
de cada cepa modulan estas interacciones. Están apareciendo nuevos aspectos acerca de las propiedades de la estabilidad en ecosistemas lacustres someros basados en estudios, experimentales o de modelización, de los aportes de materia orgánica de origen terrestre, tanto disuelta (tDOM) como particulada (tPOM). Estos estudios sugieren que la probabilidad de que los lagos someros cambien hacia o permanezcan en un estado de aguas turbias, aumenta con la predictibilidad futura de un incremento en los aportes de tDOM y tPOM. Todavía existen muchas incógnitas en la restauración de lagos someros, como la disponibilidad y dispersión de propágulos para el restablecimiento de una vegetación diversa de macrófitos sumergidos. Sin embargo, la importancia de los cambios en el estado del lago está cada vez más demostrada en trabajos que cuantifican las consecuencias para la producción primaria, las emisiones y el secuestro de carbono.

Palabras clave: Alelopatia, biestabilidad, balance de carbono, restauración de lagos, rio.

\section{INTRODUCTION}

Many ecosystems seem to exert multiple stable states and thus respond to changes in external factors with sudden state shifts (Holling, 1973; May, 1977; Scheffer et al., 2001). Barnosky et al. (2012) suggested that even the entire biosphere may be approaching a critical transition and finding suitable approaches for detecting or predicting critical transitions has become an emerging topic across many systems and disciplines (Dakos \& Hastings, 2013 and references therein). One of the best described examples of multiple stable states in ecosystems are shallow lakes that occur in either a clear, macrophyte-dominated or in a turbid, phytoplankton-dominated regime (Scheffer et al., 1993, 2001; Scheffer \& Van Nes, 2007). A theoretical concept has been developed showing how feedback mechanisms between macrophytes and water clarity result in the occurrence of alternative stable states in shallow lakes (Scheffer et al., 1993). The main stabilizing mechanisms of clear-water conditions by macrophytes were suggested to be reduced resuspension of bottom material (James et al., 2004) and increased sedimentation (Vermaat et al., 2000) inside of macrophyte stands, refuge against planktivorous fish for phytoplanktongrazing zooplankton (Timms \& Moss, 1984) as well as suppression of phytoplankton growth by competition for nutrients (Kufel \& Ozimek, 1994) and excretion of allelochemicals by macrophytes that inhibit phytoplankton growth (Hilt \& Gross, 2008). Scheffer (1998) concluded that the intensive work on shallow lakes has led to a vast expansion of our knowledge on these ecosystems, however, the array of poorly understood problems remains equally impressive. He suggested that a combination of approaches ranging from controlled experiments, whole-lake manipulations, minimal models and elaborate simulation models may be the most powerful strategy to resolve the open questions.

Here, I review recent studies that applied the concept of a clear-water stabilizing role of submerged macrophytes to other freshwater systems, namely to rivers and deeper lakes. In addition, I summarize recent findings unravelling stabilizing mechanisms in shallow lakes focussing on effects of macrophyte community composition, studies on inhibition of phytoplankton by allelochemically active macrophytes and on the impact of terrestrial organic matter on shallow lake resilience. Finally, I discuss practical and quantitative consequences of regime shifts in shallow lakes for their restoration and carbon cycling.

\section{CONCEPTS BEYOND SHALLOW LAKES}

\section{Regime shifts in rivers}

An important assumption for alternative stable states in water quality is that the endogenous feedback processes are stronger than exogenous processes (Dent et al., 2002). This assumption may often be violated for rivers that are generally considered to be open ecosystems mainly controlled by exogenous processes, particularly hydrologic regimes (Ryder \& Pesendorfer, 1989; 


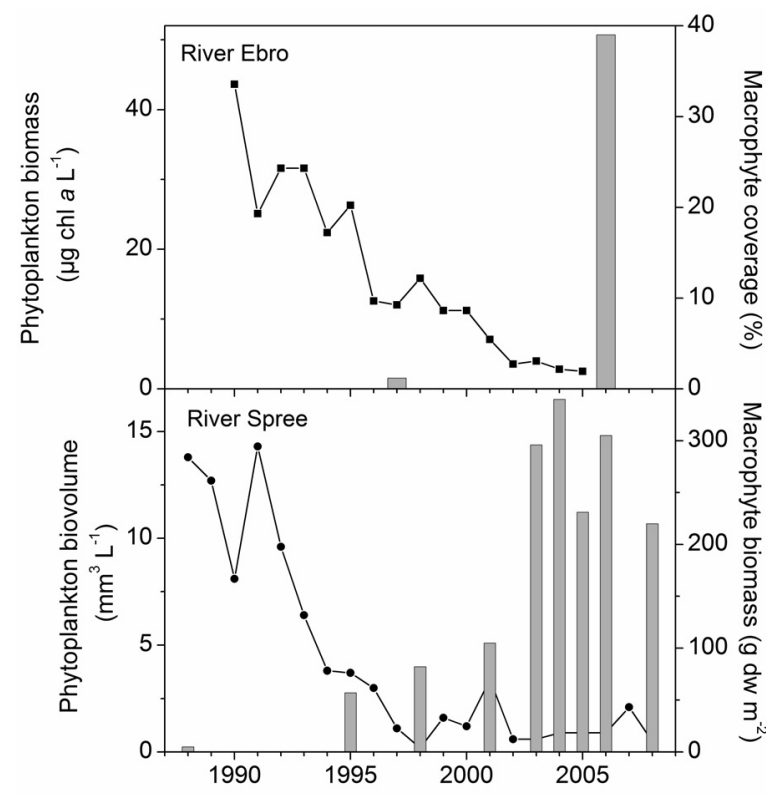

Figure 1. Development of phytoplankton and submerged macrophytes in River Ebro (data from Ibáñez et al., 2012) and River Spree (data from Hilt et al., 2011) in the period 19882008. River Ebro: annual averaged chlorophyll concentrations (line) and average macrophyte coverage (bars) measured at six locations, River Spree: seasonal means (biweekly sampling from June-September) of phytoplankton biovolume (line) and summer biomass of submerged macrophytes (bars). For years without bars, no macrophyte data were available. Error bars were omitted for clarity. Desarrollo de fitoplancton y macrófitos sumergidos en el río Ebro (Ibáñez et al., 2012) y el río Spree (Hilt et al., 2011) en el período 1988-2008. Río Ebro: concentración anual promedio de clorofila (línea) y promedio de cobertura de macrófitos (barras) medidas en seis localidades. Rio Spree: medias estacionales (muestreo quincenal de JunioSeptiembre) del biovolumen de fitoplancton (línea) y biomasa de macrófitos sumergidas en verano (barras). Los años sin barras no hubo datos disponibles de macrófitos. Las barras de error se omitieron para una mejor claridad.

Dent et al., 2002). Consequently, alternative stable states in rivers have been described for geomorphological features, although biotic components sometimes affect geomorphology (Naiman et al., 2000). Planktonic algae are unlikely to dominate in the upper reaches of all rivers and over the whole length of short rivers with a short water retention time. These are dominated by macrophytes or benthic algae and lack multiple stable states (Hilton et al., 2006). The flow of most rivers of the world, however, is regulated by dams (Nilsson et al., 2005) and postglacial lowland regions are often dominated by river- lake systems. In such systems, river stretches downstream of eutrophic lakes or reservoirs may be strongly loaded with phytoplankton (Köhler, 1994; Neal et al., 2006).

A recently developed spatially explicit simple model predicts that shifts between phytoplankton and macrophyte dominance can also occur in such rivers with high phytoplankton loading (Hilt et al., 2011). Alternative stable states only occur at low flowing velocities and thus high retention times. Hysteresis disappeared with decreasing retention times, but abrupt changes between clear and turbid states were still possible both in time and in space. A local regime shift that occurs upstream may propagate through the whole river due to a domino effect. Restoration measures such as biomanipulation in lakes, planting macrophyte stands (Larned et al., 2006) or reduction of local nutrient loading should thus start upstream and may eventually trigger regime shifts downstream (Hilt et al., 2011). The possibility of steep regime shifts between phytoplankton and macrophyte dominance in slow flowing (lowland) rivers is supported by data from River Spree (Germany) and River Ebro (Spain). Parts of both rivers went through an abrupt regime shift from phytoplankton to macrophyte dominance (Fig. 1) during a period of gradually declining nutrient concentrations (River Spree: Köhler et al., 2010; Hilt et al., 2011; River Ebro: Ibáñez et al., 2012).

The model developed by Hilt et al. (2011) consists of 100 equal, well-mixed sections receiving water from a previous section (the first section gets water from an external source). In each time unit, a fraction of the volume flows to the next section. The model is thus also valid for a chain of connected lakes and may explain the striking co-occurrence of clear-water and turbid conditions in connected shallow lakes detected by Timms \& Moss (1984) and Cottenie et al. (2001). It may also help comparing management options in chains of shallow lakes (Carpenter \& Lathrop, 2014).

\section{Regime shifts in deeper lakes}

In deep lakes and reservoirs only a smaller part of the water body can be colonised by submerged 
macrophytes and the vegetation response to changes in turbidity is not discontinuous as in shallow lakes (Scheffer et al., 1993). Submerged macrophytes have thus been widely neglected in deep lake modelling. Genkai-Kato $\&$ Carpenter (2005) modelled the effect of submerged macrophytes on water clarity and found no remarkable effect for lakes deeper than $10 \mathrm{~m}$. However, the macrophyte effects were restricted to prevention of phosphorus recycling from the sediment not including other potential interactions of submerged macrophytes within the ecosystem. In contrast, several empirical studies suggest that submerged macrophytes may significantly contribute to the stabilization of the clear-water regime in deep lakes. Hilt et al. (2010) observed a sudden and stable shift to clear-water conditions in Lake Scharmützelsee (maximum depth $29.5 \mathrm{~m}$ ) after a significant increase in submerged macrophyte coverage from $<10 \%$ to $24 \%$. Rooney \& Kalff (2003) detected an inverse relationship between phytoplankton biomass and macrophyte coverage in nine lakes with maximum depths ranging from 2 to $20 \mathrm{~m}$. This indicates a potential impact of macrophytes on phytoplankton in lakes deeper than those allowing full macrophyte coverage. In addition, Lauridsen et al. (1996) and Portielje \& Van der Molen (1999) showed that low macrophyte coverages in shallow lakes can also significantly contribute to a higher water clarity as compared to lakes without macrophytes. The impact of submerged macrophytes on the water quality in deeper lakes, even if smaller areas are colonized, might thus be underestimated.

Sachse et al. (2014) developed a one-dimensional, vertically resolved macrophyte model to test macrophyte effects on water quality in scenarios for lakes with different basin shapes and maximum depths from $11 \mathrm{~m}$ to $100 \mathrm{~m}$. Their model simulations revealed that submerged macrophytes can significantly affect the water quality of deep lakes. The presence of submerged macrophytes resulted in up to $50 \%$ less phytoplankton biomass in the shallowest simulated conic-shaped lake $(11 \mathrm{~m})$ and still $15 \%$ less phytoplankton was predicted in $100 \mathrm{~m}$ deep oli-

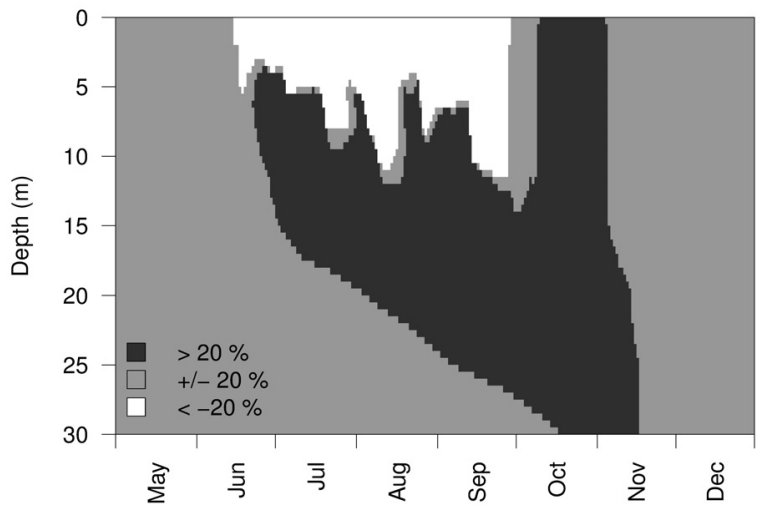

Figure 2. Relative differences of phytoplankton concentrations in a mesotrophic $30 \mathrm{~m}$ deep simulated conic lake with macrophytes as compared to a scenario without macrophytes. Shadings indicate strong negative (white) or positive (dark grey) effects which exceeded $+/-20 \%$ (modified after Sachse et al., 2014). Diferencias relativas en la concentración de fitoplancton de un lago simulado mesotrófico y cónico de $30 \mathrm{~m}$ de profundidad, entre un escenario con y sin macrófitos. Los colores indican efectos fuertemente negativos (blanco) o positivos (gris oscuro) que exceden $+/-20 \%$ (modificado de Sachse et al., 2014).

gotrophic lakes as compared to lakes without macrophytes. At intermediate depths $(30 \mathrm{~m})$, total phytoplankton biomass was reduced by at least $20 \%$ in the epilimnion throughout the whole summer, but an increase of phytoplankton was predicted for the metalimnion (Fig. 2). Overall, competition for nutrients in the open water was mainly (89\%) responsible for the simulated macrophyte effect in deep lakes. Shading contributed by $8 \%$, the provision of zooplankton shelter by $3 \%$ and reduced turbulence in macrophyte patches contributed only by $0.1 \%$ to the overall macrophyte effect (Sachse et al., 2014). Hysteresis effects were small in deep lakes, however, their response to changes in nutrient loading may still be discontinuous when the lake is close to the critical threshold level, similar to findings made for rivers (Hilt et al., 2011). Deep lakes that lost their submerged vegetation were thus supposed to also show some resilience to decreasing nutrient loading. Based on these results re-establishment of submerged macrophytes in deep lakes was suggested to be potentially as important during their restoration as in shallow lakes (Sachse et al., 2014). 


\section{MECHANISMS STABILIZING MACROPHYTE DOMINANCE}

\section{Effects of macrophyte community composition}

Currently, the importance of the effect of macrophyte community composition on ecosystem functions performed by macrophytes remains largely unknown and seems an emerging topic of research (Bakker et al., 2013). Studies on feedback mechanisms between water clarity and submerged vegetation have often been conducted in shallow lakes with dominance of angiosperms. These differ from those dominated by charophytes and often have higher nutrient concentrations. Blindow et al. (2014) hypothesized that different mechanisms prevail depending on whether charophytes or angiosperms are the dominant macrophyte group. Charophytes domi- nate at lower nutrient concentrations and can develop higher areal biomass than most angiosperms. Their influence on sedimentation, resuspension and water column nutrients is thus assumed to be higher than that of most angiosperms. In contrast, grazing pressure from zooplankton on phytoplankton is suggested to be low in characeans, but to be the main stabilizing feedback mechanism in most angiospermdominated ecosystems. Zooplankton is hampered by low food quality and quantity and at least temporarily by high predation pressure from juvenile fish inside of dense characean stands (Blindow et al., 2014). Allelopathic inhibition of phytoplankton may occur at high densities of allelopathically active species, which are present among both charophytes and angiosperms (Blindow et al., 2014). Experiments and field measurements comparing the effect of charophytes and angiosperms on water clarity

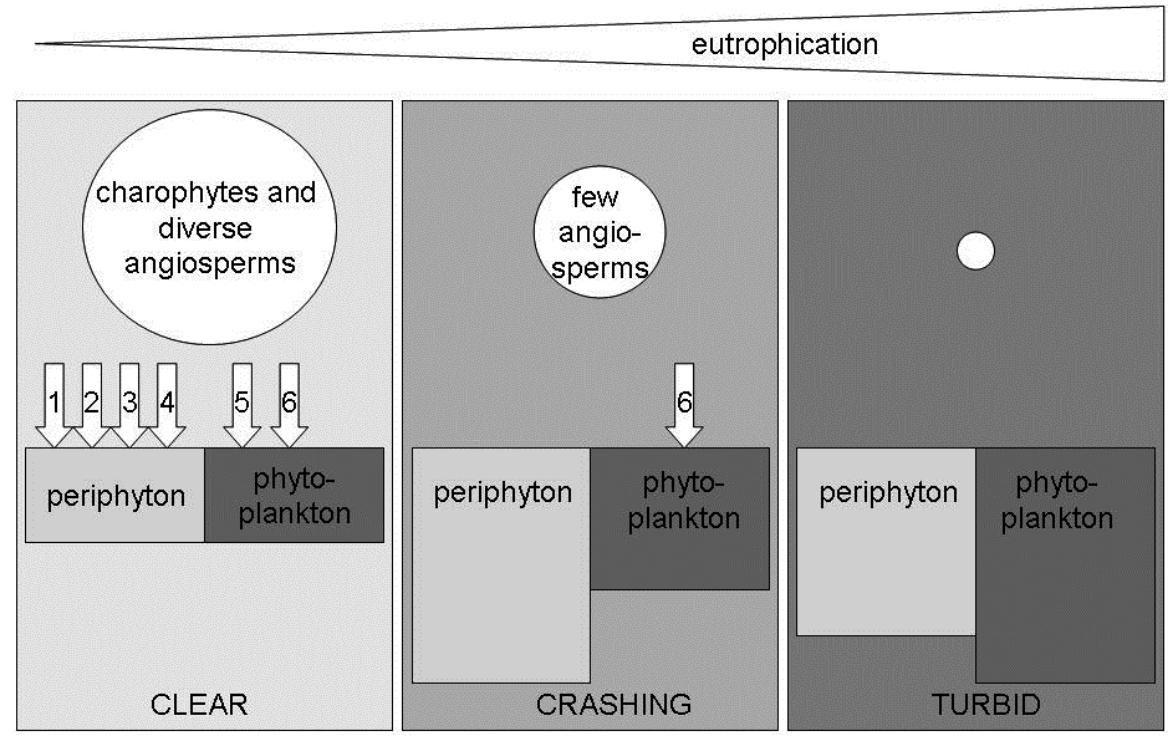

Figure 3. Development of shallow lakes during eutrophication: A diverse submerged vegetation of charophytes and angiosperms in clear lakes negatively affects both, periphyton and phytoplankton abundance via reduced sediment resuspension (1), competition for nutrients (2), provision of habitat for macrozoobenthos (3) and piscivorous fish (4), allelopathy (5) and shelter for zooplankton from predation by planktivorous fish (6). In crashing lakes, only a few angiosperms dominate and consequently, most negative effects are lost, especially those affecting periphyton. In turbid lakes, submerged vegetation is almost absent and cannot affect periphyton or phytoplankton. Evolución en lagos someros durante la eutrofización: una diversa vegetación de carófitos y angiospermas en lagos de aguas claras afectan negativamente la abundancia de perifiton y de fitoplancton vía: la reducción en la resuspensión de sedimento (1), competencia por nutrientes (2), provisión de hábitat para macrozoobentos (3), y peces piscívoros (4), alelopatía (5) y protección de la depredación del zooplancton por peces planctívoros (6). En lagos en fase "crashing”solo predominan unas pocas angiospermas y como consecuencia la mayoría de efectos negativos se pierden, especialmente los que afectan al perifiton. En lagos turbios, casi no hay vegetación sumergida y en consecuencia no afecta al perifiton o al fitoplancton. 
under similar conditions are needed to verify the hypothesized difference between charophytes and angiosperms on water clarity.

These differences in feedback mechanisms may also explain the declining negative effects of submerged vegetation on periphyton and phytoplankton during eutrophication of shallow lakes (Fig. 3). A decline in macrophyte species diversity has often been observed in temperate European shallow lakes during eutrophication already before total macrophyte disappearance (Sayer et al., 2010a, b). A typical sequence starts with a high diversity of charophytes and angiosperms characterised by high water clarity in spring and summer (Fig. 3). This diverse submerged vegetation can negatively affect both competitors for light, periphyton and phytoplankton abundance, via reduced nutrient availability from sediment resuspension, competition for nutrients, provision of habitat for macrozoobenthos and piscivorous fish, allelopathy and shelter for zooplankton from predation by planktivorous fish (Fig. 3). So-called "crashing" conditions are characterized by a dominance of few angiosperm species (Potamogeton pectinatus, P. pusillus, Zannichellia palustris; Hilt, 2006; Sayer et al., 2010b). These can provide shelter for zooplankton from predation by planktivorous fish, whereas other negative effects are lost or much less effective, especially those affecting periphyton (Fig. 3). Consequently, the water is only clear in spring but dominated by phytoplankton in late summer (Sayer et al., 2010b; Hilt et al., 2013). In turbid lakes, submerged vegetation is sparse or absent and thus cannot affect periphyton or phytoplankton (Fig. 3).

\section{Modulations of macrophyte allelopathic effects on phytoplankton}

Proving an allelopathic inhibition of phytoplankton by macrophytes at ecosystem level remains a challenge (Gross et al., 2007; Hilt \& Gross, 2008). Some of the recent field and mesocosm experiments (Hilt et al., 2006a; Vanderstukken et al., 2011; Švanys et al., 2014) indicate allelopathic effects of macrophytes on phytoplankton, whereas Lombardo et al. (2013) con- cluded that allelopathy was not explaining in situ macrophyte-phytoplankton patterns in their studied lakes. Factors that were suggested to decrease the in situ relevance of allelopathic interactions include lake size (Gasith \& Hoyer, 1997) but also photolytic and microbial degradation of allelochemicals (Bauer et al., 2012) and environmental adaptation and co-evolution of phytoplankton (Reigosa et al., 1999).

The role of heterotrophic bacteria associated with producing and target cells has long been neglected, although they may both enhance or decrease the allelopathic activity (Gross et al., 2012). Recently, bacteria degrading polyphenols, a common group of aquatic macrophyte allelochemicals (Gross, 2003), have been detected both in the vicinity of the allelochemical-excreting macrophytes (Müller et al., 2007; Hempel et $a l ., 2008,2009)$ and attached to target phytoplankton (Bauer et al., 2010; Eigemann et al., 2013a). Different algae species were found to harbour bacterial communities that were species specifically associated. However, a significant contribution of these bacteria to differences in the sensitivities of algae toward allelochemicals could not be shown (Eigemann et al., 2013a).

Al-Sheri (2010) provided first indications for adaptation of phytoplankton to allelochemicals. A green algal strain isolated from a pond with an abundant allelopathically active macrophyte species had a lower sensitivity to macrophyte extracts as compared to an algal strain from a macrophyte-free pond. Local genetic adaptation and a potential co-evolution between allelochemical donor macrophytes and acceptors, however, could not be shown in a study testing 23 different strains of the green alga Pediastrum duplex originating from ponds with and without allelopathically active macrophytes (Eigemann $e t$ al., 2013b). Differences in sensitivities of strains, however, varied by two orders of magnitude and need to be taken into account if evaluating ecological consequences of allelopathic interactions (Eigemann et al., 2013b).

In addition to the different sensitivities of strains towards allelochemicals, interactions between strains and species have to be considered. Most studies of the effects of macrophyte allelo- 
chemicals on phytoplankton were performed with single-species cultures and thus neglected this aspect. Natural phytoplankton assemblages, however, usually contain a high number of species from different phytoplankton groups that compete for nutrients and light (Kayser, 1979) or otherwise interact, e.g. via the excretion of extracellular metabolites (Keating, 1977; Graneli et al., 2008). Chang et al. (2012) showed that interactions with a green alga turned the inhibiting effect of allelochemicals on the cyanobacterium Microcystis aeruginosa into an enhancement resulting in increased growth rates of M. aeruginosa.

\section{Role of terrestrial organic matter input}

The stability properties of shallow lake ecosystems have been discussed along a gradient of nutrient loadings (Scheffer et al., 1993). Regime shifts were attributed to either passing of threshold levels in nutrient loading or strong disturbances such as reductions in fish biomass or macrophyte disappearance after storm events (Scheffer, 1998). The role of inputs of dissolved and particulate organic matter from terrestrial surroundings (tDOM, tPOM) for the stability of shallow lake ecosystems, however, has received less attention. The tDOM loading potentially affects shallow lakes ecosystems by increasing light extinction and thus affecting physical mixing and primary production (Carpenter et al., 1998; Houser et al., 2003; Houser, 2006). An oligotrophic, subarctic lake shifted towards a more heterotrophic food web under experimentally elevated tDOM fluxes (Forsström et al., 2013) and both model simulations and empirical studies showed reduced primary production in meso- to eutrophic lakes due to shading by tDOM inputs (Jones et al., 2012; Brothers et al., 2014). A model study by Lischke et al. (2014) suggested that also an enhanced $\mathrm{TPOM}$ input will reduce the resilience of the macrophytedominated clear-water state of shallow temperate lakes. Their results show that $\mathrm{POM}$ induced an increase in zoobenthos biomass resulting in more benthivorous fish, which reduced light availability due to bioturbation. An increased zoobenthos biomass by tPOC additions has been experimentally verified in a whole-lake experiment (Scharnweber, 2013; Scharnweber $e t$ al., 2014a, b). In addition, Lischke et al. (2014) predicted that suspended TPOM reduces the consumption of phytoplankton by zooplankton which increases the turbidity, and that suspended tPOM reduces the light availability for submerged macrophytes. These results resemble the effects of tDOM on light climate in lakes (Ask et al., 2009; Karlsson et al., 2009), but the presumed underlying mechanisms were different. The likelihood that shallow lakes will shift to or stay in the turbid state will thus most probably be enhanced by the predicted future increase in tDOM and tPOM input (Zaehle et al,. 2007).

\section{PRACTICAL CONSEQUENCES OF REGIME SHIFTS}

\section{Lake restoration}

Regime shifts between alternative stable states have vast effects on community structure and biodiversity with consequences for ecosystem function (Scheffer et al., 2001). Sand-Jensen et al. (2000) and Jeppesen et al. (2000) reported a reduction in species richness in lakes with high phytoplankton turbidity. Delays in the recovery of macrophyte abundance (Körner \& Dugdale, 2003; Hilt, 2006) and species diversity have often been observed during lake restoration and the diversity present prior to eutrophication may often not return at all (Bakker et al., 2013; Hilt et al., 2013). A significant increase in macrophyte species diversity may take 20 years after start of reductions in external nutrient loading, indicating that patience is needed in allowing the few species of the re-establishment phase to pave the way for a more diverse macrophyte community (Hilt et al., 2013). However, as the reestablishment of submerged macrophytes is essential for the long-term success of a restoration in shallow lakes, measures for their potential support in case of a hampered natural reestablishment and management measures in case of mass developments should be planned in ad- 
vance of any restoration effort (Hilt et al., 2006b). A cost and maintenance intensive artificial support by planting or seeding of submerged plants was supposed to be useful only under specific circumstances. These include 1) the lack of viable propagation units of submerged vegetation in the sediment and lack of submerged macrophytes in the lake or connected water bodies, 2) the application of a restoration measure that decreases turbidity only for a short time period, 3) a restoration measure including the introduction of pike (Esox lucius) that need submerged macrophyte stands for successful development or 4) the need of promoting specific (low growing) macrophyte species to enable recreational use (Hilt et al., $2006 b$ ). In general, the role of propagule availability and dispersal for the re-establishment of a diverse submerged macrophyte vegetation during lake restoration is still fairly unknown. More studies testing the importance of macrophyte diversity for maintaining clear-water conditions are needed for a better guidance of restoration efforts (Bakker et al., 2013).

\section{Regime shifts and carbon cycling}

Apart from qualitative changes, recent studies have indicated that shifts between the separate plant forms also have significant quantitative consequences for shallow lake ecosystems, e.g. for primary production, carbon (C) emissions and $\mathrm{C}$ burial. In general, eutrophic lakes with abundant primary producers (either phytoplankton or submerged macrophytes) are often undersaturated in $\mathrm{CO}_{2}$ and thus could act as net atmospheric $\mathrm{CO}_{2}$ uptake sites (Kosten et al., 2010; Balmer \& Downing, 2011). Brothers et al. (2013a) provided empirical and theoretical evidence for higher gross primary production (GPP) in small, eutrophic, shallow lakes dominated by a submerged macrophyte-epiphyton complex as compared to turbid, phytoplankton-dominated lakes of similar nutrient concentrations. Blindow et al. (2006) also found a higher net primary production (NPP) in a macrophyte-dominated lake and assumed this to be the reason for increased biomass of higher trophic levels after a shift to a clear-water state. Shifts from a turbid to a clear- water state are also accompanied by a dominance shift from a pelagic to a benthic food chain and will increase the energy transfer to higher trophic levels (Hecky \& Hesslein, 1995; Vander Zanden et al., 2006). Brothers et al. (2013b) linked regime shifts from macrophyte to phytoplankton dominance in shallow lakes to a major increase in $\mathrm{C}$ burial efficiency due to lower $\mathrm{C}$ mineralization and higher calcite precipitation. Their data indicate that nearly all $\mathrm{C}$ deposited over an annual period in a phytoplankton-dominated lake was buried in the sediments, compared to only $20 \%$ in a macrophyte-dominated lake of comparable size and nutrient concentration (Fig. 4). The lower $\mathrm{C}$ mineralization rates in the turbid lake were associated with a decrease in benthic oxygen availability coinciding with the loss of submerged macrophytes. Future research in shallow aquatic systems is thus suggested to address the potential effects of regime shifts between macrophyte and phytoplankton dominance in addition to other factors that influence $\mathrm{C}$ burial rates, such as watershed erosion and nutrient loading (Heathcote \& Downing, 2012; Theissen et al., 2012; Heathcote et al., 2013).

\section{ACKNOWLEDGEMENTS}

I am grateful to the organising committee of the XVII congress of the Iberian Association of Limnology for inviting me to address this topic. A major part of the research included in this review has been carried out by $\mathrm{PhD}$ students that I supervised or co-supervised (Nadine Bauer, Falk Eigemann, Algirdas Švanys, Soren Brothers, Kristin Scharnweber, Betty Lischke) or by postdocs (Rene Sachse) and guest scientists (Xuexiu Chang). I also thank my colleagues Ursula Gaedke, Elisabeth Gross, Hans-Peter Grossart, Jan Köhler, Thomas Mehner and all co-authors for their scientific input and the IGB technicians for their technical support. The German Research Foundation (HI 1380/3-1, 4-1, SU 623/1-1) the Leibniz Association, the China Scholarship Council and National Natural Science Foundation of China, Deutsche Bundesstiftung Umwelt and the Senate of Berlin provided financial support. 


\section{REFERENCES}

AL-SHERI, A. M. 2010. Differential sensitivities of different Scenedesmus obliquus strains to the allelopathic activity of the macrophyte Stratiodes aloides. Journal of Applied Science, 10: 17691774.

ASK, J., J. KARLSSON, L. PERSSON, P. ASK, P. BYSTROM \& M. JANSSON. 2009. Terrestrial organic matter and light penetration: effects on bacterial and primary production in lakes. Limnology \& Oceanography, 54: 2034-2040.

BAKKER, E. S., S. M. SARNEEL, R. D. GULATI, Z. LIU \& E. VAN DONK. 2013. Restoring macrophyte diversity in shallow temperate lakes: biotic versus abiotic constraints. Hydrobiologia, 710: 23-37.

BALMER, M. B. \& J. A. DOWNING. 2011. Carbon dioxide concentrations in eutrophic lakes: Undersaturation implies atmospheric uptake. Inland Waters, 1: 125-132.

BARNOSKY, A. D., E. A. HADLY, J. BASCOMPTE, E. L. BERLOW, J. H. BROWN, M. FORTELIUS, W. M. GETZ, J. HARTE, A. HASTINGS, P. A. MARQUET, N. D. MARTINEZ, A. MOOERS, P. ROOPNARINE, G. VERMEIJ, J. W. WILLIAMS, R. GILLESPIE, J. KITZES, C. MARSHALL, N. MATZKE, D. P. MINDELL, E. REVILLA \& A. B. SMITH. 2012. Approaching a state shift in earth's biosphere. Nature, 486: 52-58.

BAUER, N., H. P. GROSSART \& S. HILT. 2010. Effects of bacterial communities on the sensitivity of Stephanodiscus minutulus and Desmodesmus armatus to tannic acid. Aquatic Microbial Ecology, 59: 295-306.

BAUER, N., H. P. GROSSART, E. ZWIRNMANN \& S. HILT. 2012. Transformation and allelopathy of natural DOC and tannic acid are affected by solar radiation and bacteria. Journal of Phycology, 48: 355-365.

BLINDOW, I., A. HARGEBY, J. MEYERCORDT \& H. SCHUBERT. 2006. Primary production in two shallow lakes with contrasting plant form dominance: A paradox of enrichment? Limnology \& Oceanography, 51: 2711-2721.

BLINDOW, I., A. HARGEBY \& S. HILT. 2014. Facilitation of clear-water conditions in shallow lakes by macrophytes: differences between charophyte and angiosperm dominance. Hydrobiologia, 737: 99-110.
BROTHERS, S., S. HILT, S. MEYER \& J. KÖHLER. 2013a. Plant community structure determines primary productivity in shallow, eutrophic lakes. Freshwater Biology, 58: 2264-2276.

BROTHERS, S., S. HILT, K. ATTERMEYER, H. P. GROSSART, S. KOSTEN, T. MEHNER, N. MEYER, K. SCHARNWEBER \& J. KÖHLER. 2013b. A regime shift from macrophyte to phytoplankton dominance enhances carbon burial in a shallow, eutrophic lake. Ecosphere, 4(11): art 137.

BROTHERS, S., J. KÖHLER, N. MEYER, K. ATTERMEYER, H. P. GROSSART, T. MEHNER, K. SCHARNWEBER \& S. HILT. 2014. A feedback loop links brownification and anoxia in a temperate, shallow lake. Limnology \& Oceanography,59: 1388-1398.

CARPENTER, S. R., J. J. COLE, J. F. KITCHELL \& M. L. PACE. 1998. Impact of dissolved organic carbon, phosphorus, and grazing on phytoplankton biomass and production in experimental lakes. Limnology \& Oceanography, 43: 73-80.

CARPENTER, S. R. \& R. C. LATHROP. 2014. Phosphorus loading, transport and concentrations in a lake chain: a probabilistic model to compare management options. Aquatic Sciences, 76: 145-154.

CHANG, X., F. EIGEMANN \& S. HILT. 2012. Do macrophytes support harmful cyanobacteria? Interactions with a green alga reverse the inhibiting effects of macrophyte allelochemicals on Microcystis aeruginosa. Harmful Algae, 19: 76-84.

COTTENIE, K., N. NUYTTEN, E. MICHELS \& L. DE MEESTER. 2001. Zooplankton community structure and environmental conditions in a set of interconnected ponds. Hydrobiologia, 442:339-350.

DAKOS, V. \& A. HASTINGS. 2013. Editorial: special issue on regime shifts and tipping points in ecology. Theoretical Ecology, 6: 253-254.

DENT, C. L., G. S. CUMMING \& S. R. CARPENTER. 2002. Multiple states in river and lake ecosystems. Philosophical Transactions of the Royal Society B, 357: 635-45.

EIGEMANN, F., S. HILT, I. SALKA \& H. P. GROSSART. 2013a. Bacterial community composition associated with freshwater algae: species specificity vs. dependency on environmental conditions and source community. FEMS Microbiology Ecology, 83: 650-663.

EIGEMANN, F., P. VANORMELINGEN \& S. HILT. 2013b. Differences in sensitivities of algae towards allelochemicals are strain-specific but not corre- 
lated to the co-occurrence with allelopathic macrophytes. PLoS One, 8(10): e78463.

FORSSTRÖM, L., T. ROIHA \& M. RAUTIO. 2013. Responses of microbial food web to increased allochthonous DOM in an oligotrophic subarctic lake. Aquatic Microbial Ecology, 68: 171-184.

GASITH, A. \& M. V. HOYER. 1997. Structuring role of macrophytes in lakes: changing influence along lake size and depth gradients. In: The Structuring Role of Submerged Macrophytes in Lakes. E. Jeppesen, Ma. Søndergaard, Mo. Søndergaard \& K. Christoffersen (eds.): 381-392, Springer, New York, NY.

GENKAI-KATO, M. \& S. R. CARPENTER. 2005. Eutrophication due to phosphorus recycling in relation to lake morphometry, temperature, and macrophytes. Ecology, 86: 210-219.

GRANELI, E., M. WEBERG \& P. S. SALOMON. 2008. Harmful algal blooms of allelopathic microalgal species: the role of eutrophication. Harmful Algae, 8: 94-102.

GROSS, E. M. 2003. Allelopathy of aquatic autotrophs. Critical Reviews in Plant Sciences, 22: 313-339.

GROSS, E. M., S. HILT, P. LOMBARDO \& G. MULDERIJ. 2007. Searching for allelopathy in action state of the art and open questions. Hydrobiologia, 584: 77-88.

GROSS, E. M., C. LEGRAND, K. RENGEFORS \& U. TILLMANN. 2012. Allelochemical interactions among aquatic primary producers. In: Chemical ecology in aquatic systems. C. Brönmark \& L. A. Hansson (eds.): 196-209, Oxford University Press, New York.

HEATHCOTE, A. J. \& J. A. DOWNING. 2012. Impacts of eutrophication on carbon burial in freshwater lakes in an intensively agricultural landscape. Ecosystems, 15: 60-70.

HEATHCOTE, A. J., C. T. FILSTRUP \& J. A. DOWNING. 2013. Watershed sediment losses to lakes accelerating despite agricultural soil conservation efforts. PLoS One, 8: e53554.

HECKY, R. E. \& R. H. HESSLEIN. 1995. Contributions of benthic algae to lake food webs as revealed by stable isotope analysis. Journal of the North American Benthological Society, 14: 631-653.

HEMPEL, M., M. BLUME, I. BLINDOW \& E. M. GROSS. 2008. Epiphytic bacterial community composition on two common submerged macrophytes in brackish water and freshwater. $B M C M i$ crobiology, 8: 58 .
HEMPEL, M., H. P. GROSSART \& E. M. GROSS. 2009. Community composition of bacterial biofilms on two submerged macrophytes and an artificial substrate in a pre-alpine lake. Aquatic $\mathrm{Mi}$ crobial Ecology, 58: 79-94.

HILT, S. 2006. Recovery of Potamogeton pectinatus L. stands in a shallow eutrophic lake under extreme grazing pressure. Hydrobiologia, 570: 95-99.

HILT, S. \& E. M. GROSS. 2008. Can allelopathically active submerged macrophytes stabilise clearwater states in shallow eutrophic lakes? Basic and Applied Ecology, 9: 422-432.

HILT, S., M. GHOBRIAL \& E. M. GROSS. 2006a. In situ allelopathic potential of Myriophyllum verticillatum (Haloragaceae) against selected phytoplankton species. Journal of Phycology, 42: 11891198.

HILT, S., E. M. GROSS, M. HUPFER, H. MORSCHEID, J. MÄHLMANN, A. MELZER, J. POLTZ, S. SANDROCK, E.-M. SCHARF, S. SCHNEIDER \& K. VAN DE WEYER. 2006b. Restoration of submerged vegetation in shallow eutrophic lakes -guideline and state of the art in Germany. Limnologica, 36: 155-171.

HILT, S., I. HENSCHKE, J. RÜCKER \& B. NIXDORF. 2010. Can submerged macrophytes influence turbidity and trophic state in deep lakes? Suggestions from a case study. Journal of Environmental Quality, 39: 725-733.

HILT, S., J. KÖHLER, H. P. KOZERSKI, M. SCHEFFER \& E. VAN NES. 2011. Abrupt regime shifts in space and time along rivers and connected lakes systems. Oikos, 120: 766-775.

HILT, S., R. ADRIAN, J. KÖHLER, M. T. MONAGHAN \& C. D. SAYER. 2013. Clear, crashing, turbid and back-long-term changes of macrophyte assemblages in a shallow lake. Freshwater Biology, 58: 2027-2036.

HILTON, J., M. O' HARE, M. J. BOWES \& J. I. JONES. 2006. How green is my river? A new paradigm of eutrophication in rivers. Science of the Total Environment, 365: 66-83.

HOLLING, C. S. 1973. Resilience and stability of ecological systems. Annual Review of Ecology and Systematics, 4: 1-24.

HOUSER, J. N. 2006. Water color affects the stratification, surface temperature, heat content, and mean epilimnetic irradiance of small lakes. Canadian Journal of Fisheries and Aquatic Sciences, 63: 2447-2455. 
HOUSER, J. N., D. L. BADE, J. J. COLE \& M. L. PACE. 2003. The dual influences of dissolved organic carbon on hypolimnetic metabolism: organic substrate and photosynthetic reduction. Biogeochemistry, 64: 247-269.

IBÁÑEZ, C., C. ALCARAZ, N. CAIOLA, A. ROVIRA, R. TROBAJO, M. ALONSO, C. DURAN, P. J. JIMÉNEZ, A. MUNNÉ, \& N. PRAT. 2012. Regime shift from phytoplankton to macrophyte dominance in a large river: Top-down versus bottom-up effects. Science of the Total Environment, 416: 314-322.

JAMES, W. F., E. P. BEST \& J. W. BARKO. 2004. Sediment resuspension and light attenuation in Peoria Lake: can macrophytes improve water quality in this shallow system? Hydrobiologia, 515: 193-201.

JEPPESEN, E., J. P. JENSEN, M. SØNDERGAARD, T. LAURIDSEN \& F. LANDKILDEHUS. 2000. Trophic structure, species richness and biodiversity in Danish lakes: changes along a phosphorus gradient. Freshwater Biology, 45: 201-218.

JONES, S. E., C. T. SOLOMON \& B. C. WEIDEL. 2012. Subsidy or substraction: how do terestrial inputs influence consumer production in lakes? Freshwater Reviews, 5: 37-49.

KARLSSON, J., P. BYSTROM, J. ASK, P. ASK, L. PERSSON \& M. JANSSON. 2009. Light limitation of nutrient-poor lake ecosystems. Nature, 460: 506-509.

KAYSER, H., 1979. Growth interactions between marine dinoflagellates in multispecies culture experiments. Marine Biology, 52: 357-369.

KEATING, K. I., 1977. Allelopathic influence on blue-green bloom sequence in a eutrophic lake. Science, 196: 885-887.

KÖHLER, J. 1994. Origin and succession of phytoplankton in a river-lake-system (Spree, Germany). Hydrobiologia, 289: 73-83.

KÖHLER, J., J. HACHOL \& S. HILT. 2010. Regulation of submersed macrophyte biomass in a temperate lowland river: Interactions between shading by bank vegetation, epiphyton and water turbidity. Aquatic Botany, 92: 129-136.

KÖRNER, S. \& T. DUGDALE. 2003. Is roach herbivory preventing re-colonization of submerged macrophytes in a shallow lake? Hydrobiologia, 506-509: 497-501.

KOSTEN, S., F. ROLAND, D. M. L. DA MOTTA MARQUES, E. H. VAN NES, N. MAZZEO, L. DA S. L. STERNBERG, M. SCHEFFER \& J. J.
COLE. 2010. Climate-dependent $\mathrm{CO}_{2}$ emissions from lakes. Global Biogeochemical Cycles, 24: GB2007.

KUFEL, L. \& T. OZIMEK. 1994. Can Chara control phosphorus cycling in Lake Lukajno (Poland)? Hydrobiologia, 275/276: 277-283.

LARNED, S. T., A. M. SUREN, M. FLANAGAN, B. J. F. BIGGS \& T. RIIS. 2006. Macrophytes in urban stream rehabilitation: establishment, ecological effects, and public perception. Restoration Ecology, 14: 429-440.

LAURIDSEN, T., L. J. PEDERSEN, E. JEPPESEN \& M. SØNDERGAARD. 1996. The importance of macrophyte bed size for composition and horizontal migration of cladocerans in a shallow lake. Journal of Plankton Research, 18: 2283-2294.

LISCHKE, B., S. HILT, J. H. JANSE, J. J. KUIPER, T. MEHNER, W. M. MOOIJ, \& U. GAEDKE. 2014. Enhanced input of allochthonous organic matter reduces the resilience of the clear-water state of shallow lakes -a model study. Ecosystems, 17: 616-626.

LOMBARDO, P., M. MJELDE, T. KÄLLQVIST $\&$ T. BRETTUM. 2013. Seasonal and scaledependent variability in nutrient- and allelopathymediated macrophyte-phytoplankton interactions. Knowledge and Management of Aquatic Ecosystems, 409: 10.

MAY, R. M. 1977. Thresholds and breakpoints in ecosystems with a multiplicity of states. Nature, 269: 471-477.

MÜLLER, N., M. HEMPEL, B. PHILLIP \& E. M. GROSS. 2007. Degradation of gallic acid and hydrolysable polyphenols is constitutively activated by the freshwater plant-associated bacterium Matsuebacter sp. FB 25. Aquatic Microbial Ecology, 47: 83-90.

NAIMAN, R. J., S. R. ELLIOTT, J. M. HELFIELD \& T. C. O'KEEFE. 2000. Biophysical interactions and the structure and dynamics of riverine ecosystems: the importance of biotic feedbacks. Hydrobiologia, 410: 79-86.

NEAL, C., J. HILTON, A. J. WADE, M. NEAL \& H. WICKHAM. 2006. Chlorophyll-a in the rivers of eastern England. Science of the Total Environment, 365: 84-104.

NILSSON, C., C. A. REIDY, M. DYNESIUS \& C. REVENGA. 2005. Fragmentation and flow regulation of the world's large river systems. Science, 308: 405-408. 
PORTIELJE, R. \& D. T. VAN DER MOLEN. 1999. Relationships between eutrophication variables: From nutrient loading to transparency. Hydrobiologia, 408/409: 375-387.

REIGOSA, M. J., A. SANCHEZ-MOREIRAS \& L. GONZALEZ. 1999. Ecophysiological approach in allelopathy. Critical Review in Plant Sciences, 18: 577-608.

ROONEY, N. \& J. KALFF. 2003. Interactions among epilimnetic phosphorus, phytoplankton biomass and bacterioplankton metabolism in lakes of varying submerged macrophyte cover. Hydrobiologia, 501: 75-81.

RYDER, R. A. \& J. PESENDORFER. 1989. Large rivers are more than flowing lakes: a comparative review. In: Proceedings of the International Large River Symposium. Canadian Special Publication on Fisheries and Aquatic Sciences, 106. D. P. Dodge (ed.): 65-85.

SACHSE, R., T. PETZOLDT, M. BLUMSTOCK, S. MOREIRA MARTINEZ, M. PÄTZIG, J. RÜCKER, J. H. JANSE, W. M. MOOIJ \& S. HILT. 2014. Extending one-dimensional models for deep lakes to simulate the impact of submerged macrophytes on water quality. Environmental Modelling \& Software, 61: 410-423.

SAND-JENSEN, K., T. RIIS, O. VESTERGAARD \& S. E. LARSEN. 2000. Macrophyte decline in Danish lakes and streams over the past 100 years. Journal of Ecology, 88: 1030-1040.

SAYER, C. D., A. BURGESS, K. KARI, T. A. DAVIDSON \& N. ROSE. 2010a. Long-term dynamics of submerged macrophytes and algae in a small and shallow, eutrophic lake: implications for the stability of macrophyte-dominance. Freshwater Biology, 55: 565-583.

SAYER, C. D., T. A. DAVIDSON \& J. I. JONES. 2010b. Seasonal dynamics of macrophytes and phytoplankton in shallow lakes: a eutrophicationdriven pathway from plants to plankton? Freshwater Biology, 55: 500-513.

SCHARNWEBER, K. 2013. The effects of structural complexity on ecological and evolutionary processes in shallow lake ecosystems. PhD thesis, Freie Universität Berlin.

SCHARNWEBER, K., J. SYVÄRANTA, S. HILT, M. BRAUNS, M. J. VANNI, S. BROTHERS, J. KÖHLER, J. KNEŽEVIć-JARIć \& T. MEHNER. 2014a. Whole-lake experiments reveal the fate of terrestrial particulate organic carbon in ben- thic food webs of shallow lakes. Ecology, 95: 1496-1505.

SCHARNWEBER, K., M. J. VANNI, S. HILT, J. SYVÄRANTA \& T. MEHNER. 2014b. Boomerang ecosystem subsidies: Organic carbon inputs from land to lakes are returned to terrestrial food webs via aquatic insects. Oikos, 123: 1439-1448.

SCHEFFER, M. 1998. Ecology of Shallow Lakes. Chapman \& Hall, London.

SCHEFFER, M., S. H. HOSPER, M. L. MEIJER, B. MOSS \& E. JEPPESEN. 1993. Alternative equilibria in shallow lakes. Trends in Evolution and Ecology, 8: 275-279.

SCHEFFER, M., S. R. CARPENTER, J. A. FOLEY, C. FOLKE \& B. WALKER. 2001. Catastrophic shifts in ecosystems. Nature, 413: 591-596.

SCHEFFER, M. \& E. H. VAN NES. 2007. Shallow lakes theory revisited: various alternative regimes. Hydrobiologia, 84: 455-466.

ŠVANYS, A., R. PAŠKAUSKAS \& S. HILT. 2014. Effects of the allelopathically-active macrophyte Myriophyllum spicatum on a natural phytoplankton community -a mesocosm study. Hydrobiologia, 737: 57-66.

THEISSEN, K. M., W. O. HOBBS, J. M. RAMSTACK HOBBS, K. D. ZIMMER, L. M. DOMINE, J. B. COTNER \& S. SUGITA. 2012. The altered ecology of Lake Christina: A record of regime shifts, land-use change, and management from a temperate shallow lake. Science of the Total Environment, 433: 336-346.

TIMMS, R. M. \& B. MOSS. 1984. Prevention of growth of potentially dense phytoplankton populations by zooplankton grazing, in the presence of zooplanktivorous fish, in a shallow wetland ecosystem. Limnology \& Oceanography, 29: 472-486.

VANDER ZANDEN, M. J., S. CHANDRA, S. PARK, Y. VADEBONCOEUR \& C. R. GOLDMAN. 2006. Efficiencies of benthic and pelagic trophic pathways in a subalpine lake. Canadian Journal of Fisheries and Aquatic Sciences, 63: 2608-2620.

VANDERSTUKKEN, M., N. MAZZEO, W. VAN COLEN, S. A. J. DECLERCK \& K. MUYLAERT. 2011. Biological control of phytoplankton by the subtropical submerged macrophytes Egeria densa and Potamogeton illinoensis: a mesocosm study. Freshwater Biology, 56: 1837-1849.

VERMAAT, J. E., L. SANTAMARIA \& P. J. ROOS. 2000. Water flow across and sediment trapping in submerged macrophyte beds of contrasting growth 
form. Archiv für Hydrobiologie, 148: 549-562.

ZAEHLE, S., A. BONDEAU, T. CARTER, W. CRAMER, M. ERHARD, I. PRENTICE, I. REGINSTER, M. ROUNSEVELL, S. SITCH, B. SMITH,
P. SMITH \& M. SYKES. 2007. Projected changes in terrestrial carbon storage in Europe under climate and land-use change, 1990-2100. Ecosystems, 10: 380-401. 